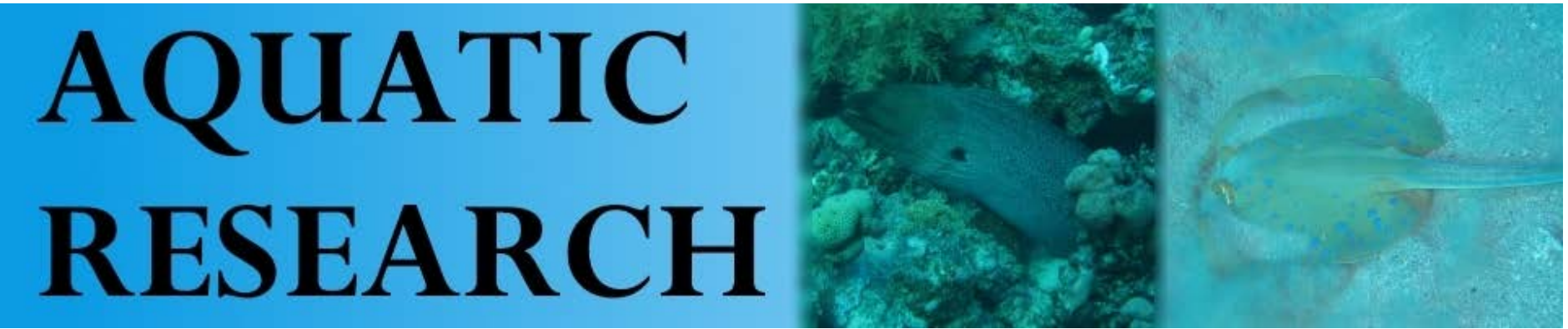

\title{
A CONTEMPORARY ANALYSIS ON FISH FARMS AND THE SAFETY OF NAVI GATI ON
}

\author{
Cahit İstikbal $^{1}$, Nuray Erkan $^{2}$ î.
}

\section{Cite this article as:}

İstikbal, C., Erkan, N. (2018). A Contemporary Analysis on Fish Farms and the Safety of Navigation. Aquatic Research, 1(1), 18-25. DOI: $10.3153 / A R 18003$

\footnotetext{
1 Maritime Transportation and Management Engineer and Chief Pilot, Republic of Turkey Ministery of Transport Maritime Affairs and Communications, Directorate General of Coastal Safety, Istanbul, Turkey

2 Istanbul University, Faculty of Aquatic Sciences, Department of Seafood Processing Technology and Safety, Istanbul, Turkey

- This publication presented as oral presentation at the Pilotage / Towage Services and Technologies Congress 2017 (27-28 October 2017, Izmir, Turkey)
}

Submitted: 03.12.2017

Accepted: 23.01.2018

Published online: 26.01 .2018

Correspondence:

Cahit İSTİKBAL

E-mail: cahit@istikbal.org

๑Copyright 2018 by ScientificWebJournals Available online at

http://aquatres.scientificwebjournals.com

\begin{abstract}
Areas where fish farms are located and are not usually far from the shore pose a risk to maritime safety. In this regard, the issue has two important aspects: first, navigational hazards on the approach to and proximity to fish farms, such as rocky, shallow, narrow passages, areas with intensive local traffic that are challenging the safety of navigation; the second is the need for a pilot and tugboat (s) for docking or undocking manoeuvres to fish farms with a berth. The offshore aquaculture has made a great leap forward since 2007, but with this development, important issues such as ecosystem conservation, sustainability of seafood, preventing marine transportation related accidents and due measures which should be put into effect gained importance as well. The cultured fish which harvested from cages usually being transported to the processing facilities and customs control locations by vessels. The maritime accidents that may occur during this transportation period have the capacity to harm both the farms and the the ecosystem significantly. As a method for this article, the safety needs of the vessels serving to the fish farms in the cargo transfers are determined, and after this determination, conclusions on how this need can be resolved by use of pilotage and towage services are put forward.
\end{abstract}

Keywords: Fish farms, Maritime pilotage, High risk marine environment, Maritime Safety, Pilotage regulations, Navigational hazards, Ecosystem, Sustainability, Seafood 


\section{Introduction}

Approximately, 71 percent of the Earth's surface is covered with water. Most of these waters are suitable for the living of many different aquatic organisms. These creatures have a wide distribution ranging from single cells to mammals. People benefit from aquatic population, especially fish, as a source of food. Fishing has been an important source of income for people since ancient times. Today, fishing is an important resource not only for coastal countries but also for countries with lakes and rivers and rich regions. Countries which are aware of the importance of balanced nutrition have focused on the best use of water resources to improve animal resources and have developed projects on this purpose.

Today, fisheries activities depend on two main sources. The first one is capture and the other is aquaculture. Today, the share of fish farms within these two sources is increasing day by day. In our country, the aquaculture first came up the 1980s, but however, its background is as old as human history. If we take a brief look at the history of aquaculture in the world; we see that in about 2000 BC, carp production in China and tilapia production in Egypt had started. Apparently, this was not a modern production since it was carried out by feeding of juvenil fishes collected from nature. There are findings of oyster farming in Greece dating back to $600 \mathrm{BC}$. In the 15th century, the culture of fishery products began by catching and feeding the fish that entered the brackish waters in Italy. In the 18th century, the first application of fish culture began with the artificial insemination on salmon fish. Oyster farming began in the 19th century. Rainbow trout production increased rapidly in Europe and North America in 1960s, while the first eel culture began in Japan in the same year. In 1970, at the allocated sea areas, preproduction trials for marine fish culture were started. In 1980, the modern aquaculture era began with the development of production techniques of fishes such as salmon, shrimp, sea bream and sea bass. In 1990, important steps were taken with studies on species such as turbot, sturgeon, lagos and tropical sea bass. From the 2000s, until today, new species and their production experiments as well as infrastructure studies have been carried out in order to produce mainline species in more economical ways. These include genetic studies, studies on vaccination and on strenghtening the immune system, stock control, food, feeding and the environment. (Rabanal, 1988).

While the world's total fish production consisting of capture and aquaculture was around 20 million tons in the year of 1950, there had been a significant increase in fish breeding at the beginning of 1980s which resulted a hike in fish production where capture production reached to 70 million tons and aquaculture production to 80 million tons. According to FAO 2014 data, the capture production value was around 80 million tons while the aquaculture production value exceeded 160 million tons. Fish consumption per person in the world has risen from an average of $9.9 \mathrm{~kg}$ in 1960 to $14.4 \mathrm{~kg}$ in 1990 and $19.7 \mathrm{~kg}$ in 2013 and the preliminary estimates for 2014 and 2015 indicated a further growth of $20 \mathrm{~kg}$. Capture and aquaculture productions are now at an equal level in terms of their contribution to meet the individual consumption demand of fish worldwide (FAO 2016).

Table 1. Fisheries and aquaculture production (million tonnes) and utilization production in world (FAO, 2016)

\begin{tabular}{|l|l|l|l|l|l|l|}
\hline Production & $\mathbf{2 0 0 9}$ & $\mathbf{2 0 1 0}$ & $\mathbf{2 0 1 1}$ & $\mathbf{2 0 1 2}$ & $\mathbf{2 0 1 3}$ & $\mathbf{2 0 1 4}$ \\
\hline Capture & & & & & & \\
\hline Inland & 10.5 & 11.3 & 11.1 & 11.6 & 11.7 & 11.9 \\
\hline Marine & 79.7 & 77.9 & 82.6 & 79.7 & 81.0 & 81.5 \\
\hline Total capture & 90.2 & 89.1 & 93.7 & 91.3 & 92.7 & 93.4 \\
\hline Aquaculture & & & & & & \\
\hline Inland & 34.3 & 36.9 & 38.6 & 42.0 & 44.8 & 47.1 \\
\hline Marine & 21.4 & 22.1 & 23.2 & 24.4 & 25.5 & 26.7 \\
\hline Total Aquaculture & 55.7 & 59.0 & 61.8 & 66.5 & 70.3 & 73.8 \\
\hline TOTAL & 145.9 & 148.1 & 155.5 & 157.8 & 162.9 & 167.2 \\
\hline $\begin{array}{l}\text { Utilization (data in this section for 2014 are provi- } \\
\text { sional estimates }\end{array}$ & & & & & \\
\hline Human consumption & & & & & & \\
\hline Non-food uses & 123.8 & 128.1 & 130.8 & 136.9 & 141.5 & 146.3 \\
\hline Population (billions) & 22.0 & 20.0 & 24.7 & 20.9 & 21.4 & 20.9 \\
\hline Per capita food fish supply (kg) & 6.8 & 6.9 & 7.0 & 7.1 & 7.2 & 7.3 \\
\hline
\end{tabular}

*Note: Excluding aquatic plants. Totals may not match due to rounding

A healthy diet has to include sufficient proteins containing all essential amino acids, essential fats (e.g. long-chain

omega-3 fatty acids), vitamins and minerals. Due to it's being a rich source with regard to these nutrients, seafood has 
vital importance. It is rich in various vitamins, especially $\mathrm{D}$, A and B vitamins as well as minerals, including calcium, iodine, zinc, iron and selenium. Seafood, especially fish, is a source of easily digested, high-quality protein containing all essential amino acids. In addition, fatty fish is usually high in unsaturated fats, particularly long-chain omega-3 fatty acids. Omega-3 fatty acids provide health benefits in protection against cardiovascular diseases and assists in development of the brain and nervous system in the foetus and infants (Erkan and Özden, 2007; Erkan, 2013).

According to Turkish Statistical Institution data, total capture production value of Turkey in 2015 was 672.241 tonnes. In this amount of production, the share of sea and inland waters is 431.907 tonnes. The share of aquaculture was 240.334 tonnes (Anonymus 2017a).

A large part of the aquaculture production in our country consists of sea bream and sea bass. Red porgy and meagre follow these two. Another fish product that has an important potential in breeding is the tuna fish. Thunnus thynnus, known as the "bluefin tuna", is the most important species in tuna fish breeding. The fry of this species are obtained from wild and breeding in pens. In our country, fish production at sea is done in the form of cage fishery in the regions of İzmir (Karaburun and Çandarlı) and Mugla (Offshore the Gulf of Güllük). The total number of aquaculture facilities in the sea is 425,77 of which are capable of operating with a capacity of over 1000 tons and 156,470 tons / year of production.

Regulation on fish farms was made with the official gazette numbered 26413 dated 24 January 2007. Accordingly, it is aimed to protect the semi-closed bay and bay areas, which are caleed as "sensitive areas", against pollution. Within this scope, establishment of fish farms has been banned at the bay and gulf areas which were defined as sensitive areas. Fish farms are allowed to be installed at certain sea areas deeper than 30 meters and at least 0.6 nautical miles offshore, with greater capacity. Offshore aquaculture has shown great improvement since 2007, bringing with it the issues that need to be considered. The areas that fish farms cover at sea vary according to their capacities. Fish harvesting from the pools, fish processing and transportation to the customs area are carried out by vessels. Possible sea accidents in this process are likely to cause significant damage to fish farms and employees as well as to the ecosystem.

Areas where fish farms are located are usually not far from the shore and this is a challenge for the navigation of ships. The need for an expert navigator with the local knowledge and experience is of great importance with regard to maritime safety. Pilotage and where necessary towage services for berthing or unberthing maneuvers to fish farms with a berth is therefore an essential solution for maritime safety. The purpose of this article is to determine the safety needs of the vessels used in the cargo transfers from and to the fish farms, and then to determine the results of pilotage and towage services and how to resolve this need.

\section{Materials and Methods}

This study examines the types of marine accidents that occurred in aquaculture farms and the precautions to be taken.

\section{Results and Discussion}

The ship named Lady Tuna was hard aground on the rocks near Fener Adası near the Ildırı area of Çeşme district near İzmir on 18 December 2016. The vessel had just harvested tuna fish at the farm belonging to Sagun Shipping and was on her way to customs area when the ship's captain, while unfamiliar with the area, wanted to make s shortcut by passing through the Fener Island. The captain, with no knowledge of the rocks just one meter beneath the surface, caused the ship going aground on these rocks. Soon after the accident, Coast Guard and Port Authority officials came to the scene. In the first survey made, it was found out that there was a rupture in the ship's hull and that the ingressing water was being pumped out. The Lady Tuna was a 2007built, having 4538 GT of volume capacity, 120 meters LOA, and Panama-flagged vessel. The ship used to come to tuna farms in Ildırı Bay every year during the harvesting season of tuna which usually was between November and February. It was estimated that approximately 200-250 tons of fish was onboard the ship at the time of accident, as an average of 30 tonnes of tuna fish per day was usually harvested from fish farms in this area. After the customs clearance process was completed, the ship would go to Malta or Croatia to transfer her cargo to larger vessels, provided the accident had not happened. Due to fuel-oil leaks after the accident, the world-famous turquoise blue waters of Çesme were covered with black colour. After the accident, the cleaning teams started to work. Izmir Environment and Urban Planning Directorate stated that the area surrounding Paşalimanı was the most badly affected area from pollution. The residents of the district and non-governmental organizations criticized the authorities for their delayed intervention. The ship was refloated one to two miles away from the coast 10 days later (Picture 2.). 
The characteristics of Lady Tuna named ship are given below (Anonymus 2017b);

- IMO: 9453418

- MMSI: 374762000

- CALL SIGN: 3EQX2

- FLAG: Panama [PA]

- AIS Vessel Type: Other

- Vessel Type: REEFER

- Gross Tonnage: 4538

- Detveyt: $4867 \mathrm{t}$

- Length Overall x Breadth Extreme: $120.75 \mathrm{~m} \times 16.6 \mathrm{~m}$

- Build: 2007

Area of Accident: Paşalimanı area and Ilıca-Yıldız Burnu coast in the Çeşme district of the Aegean province of İzmir (Picture 1)

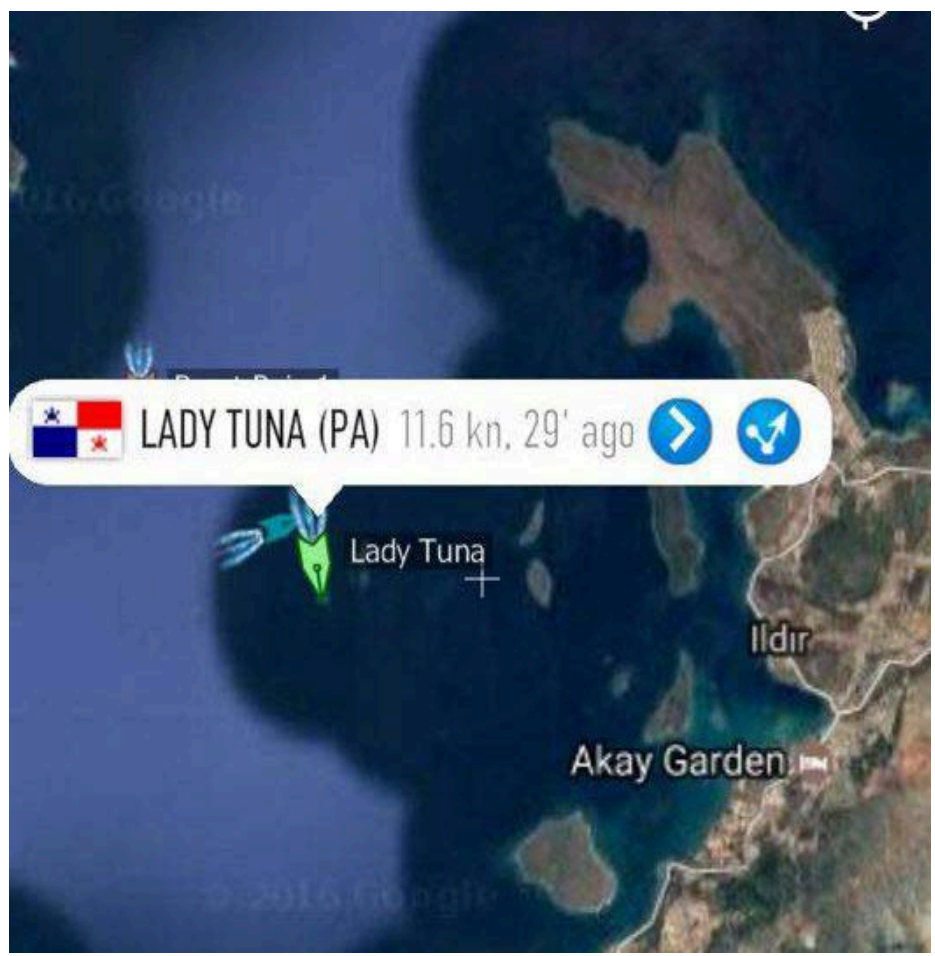

Picture 1. The area of accident

After this accident, the Turkish Maritime Administration (Ministry of Transportation, Maritime Affairs and Communication) considered that it was necessary to make amendments to the current legislation, including preventive measures for maritime accidents near fish farms. A new Article, the Article 3.1 added to the "Regulation on the Amendment of the Regulation on the Ports" and published in the Official Gazette dated on April 8, 2017 and numbered 30032, ruled that "All tankers and vessels or sea vehicles carrying dangerous cargo which are 500 GT or above, all
Turkish flagged vessels and sea vehicles of 1000 GT or above, all foreign flagged vessels and sea vehicles of 500 GT and above, commercial and private yachts of 1000 GT and above will be subject to compulsory pilotage while arriving to or departing from the coastal facilities and fish farms." Thus, a necessary requirement with regard to pilotage and towage services in the Turkish legislation with regard to maritime safety was resolved with this amendment. Safety offshore fish farming, which formed an important place in the Turkish economy, was addressed by integrating with the principle of "safety" and "public benefit" expected from the pilotage services.

Sea areas surrounding the fish farms are usually a kind of high risk marine environment, as they are placed near or within archipelagos, shallow waters, islands that are difficult to navigate. The safety of navigation in such areas, especially for vessels of larger tonnage transporting the harvested fish at farms is vital for the sustainability of life in this environment. In the case of an accident, both the marine environment in the region and the fish farms themselves can be adversely affected.

Pilotage and towage services are services that have proven themselves to provide maritime safety in difficult waters. As an indication of that, the International Maritime Organization (IMO) has adopted resolutions that strongly recommending to use pilot in a number of high risk areas around the world, including the Danish Straits, Turkish Straits and Great Barrier Reef. Therefore, this compulsory pilotage regulation implemented by the Republic of Turkey is another good example in order to protect the marine environment in or near which the fish farms are located and ensure the safety of the sea area in question. The widespread use of this example in places suitable for world scale will contribute positively to marine safety and the sustainability of fish farms.

As seen in the example of Lady Tuna accident, the risks of marine transportation are measured by environmental pollution, economic loss, injury or loss of life (Zhang et al., 2016). The safety of maritime traffic is great for the entire environment, not just for ships and their crew. The human factor is very important, although risks seem to be minimized by using modern systems and devices for the safety of maritime transport (Wu et al., 2017). The risk at maritime environment can not be eliminated to zero level, therefore it is essential to minimize the risk at acceptable levels. (Istikbal, 2007). In order for this to happen, properly assessed risk and risk management is required (Zhang et al., 2016). The greatest advantage of risk assessment is that it can be 
done before an accident, and prevents accidents through taking near misses into account. In this regard, it is of great importance to record and evaluate near misses in risk assessments (Wang, 2006; İstikbal, 2007; Zhang et al., 2016). Risk management includes continual improvement that enables hazard identification, risk assessment, quick notification, emergency response, and continued improvement of risk management of maritime traffic (İstikbal, 2007; Ece, 2016, İstikbal, 2016). Pilotage and towage services are the most efficient factor in preventing maritime accidents (İstikbal, 2007; Ece, 2016). Pilots and their competency are important factors in defining, evaluating and managing the risk. The professional experience, communication and language skills of the pilot is important for the evaluation and management of the risk, which is essential in ensuring the safety (Hsu, 2012). In Turkey, this risk was assessed after the accident that took place in fish farms area and consequently the legal arrangement was made. We have not heard if any similar regulation exists in Spain, Italy, Tunisia, Norway, Scotland, which are also countries that produce fish in the sea.
However, it is obvious that the implementation in Turkey will be an example.

There is always room for probability of M/V Lady Tuna type accidents in fish farms which are established near coastal areas. The harvesting and transporting of fish from farms by vessels should be carried out in the presence of a experienced pilot who will be able to assess the location of these farms in the marine traffic area, their meteorological and geographical conditions and possible risks. Apart from M/V Lady Tuna type accidents, there is information that small boats like yachts or even vessels crash into fish farms (Picture 3).

The accident seen in pictures 4 and 5, took place in 2011 in a sea bream-seabass fish farm off Turkey's İzmir-Karaburun district. A dry cargo ship, flying Cook Islands flag, due to a human error, chose the shortest route while navigating on auto-pilot, which ended with crashing into the fish farm. Crashing into to the cages caused serious damage to the farm, and large number of farm fish were released into the marine environment.

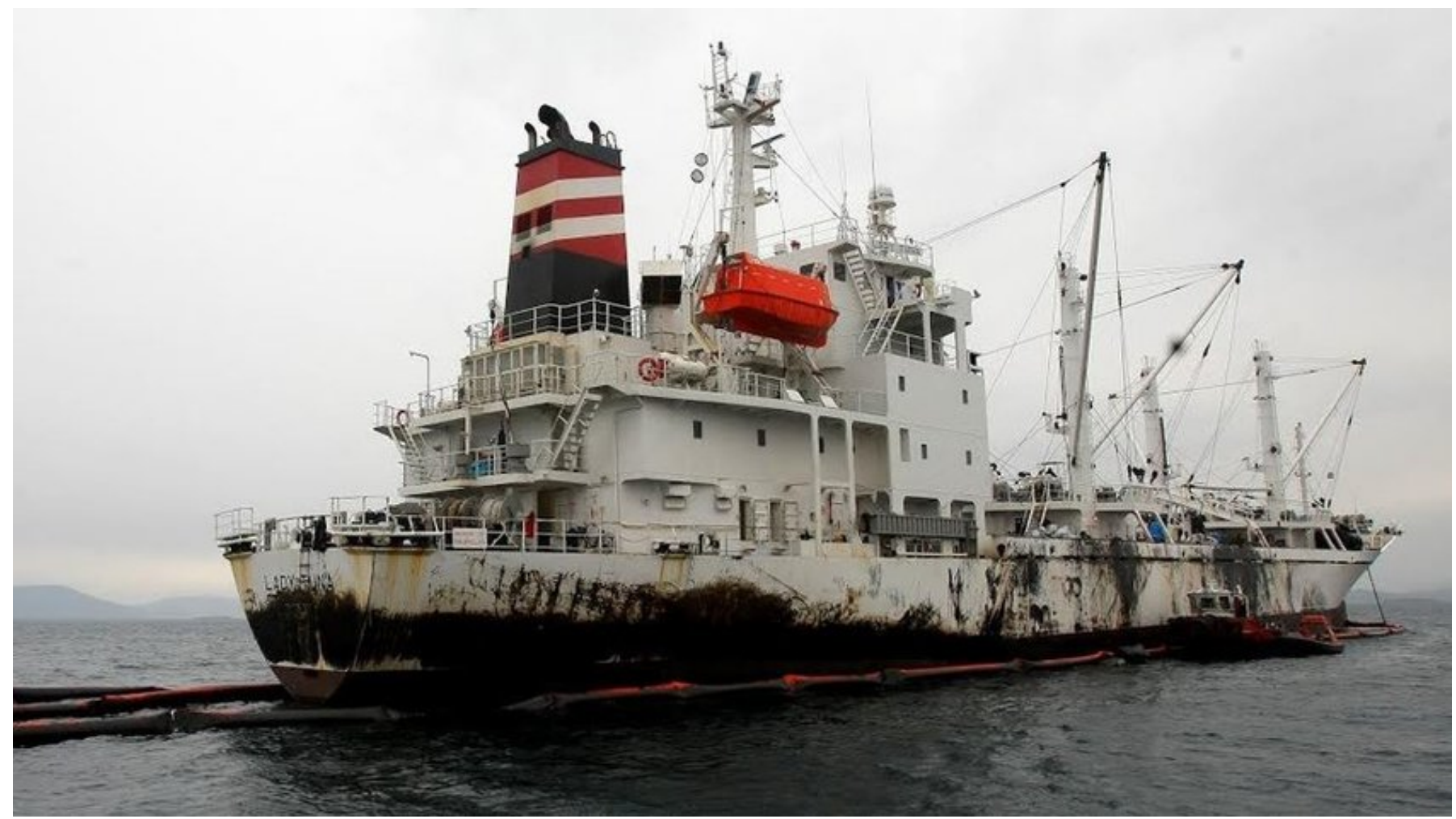

Picture 2. Booms used to control the pollution arising from M/V Lady Tuna (Anonymus, 2017c)

The damage, either physical, environmental or financial, caused by such accidents to fish farms can be extensive. As the result of an accident and damage to the cage nets, the high amount of farm fish may be released to the ecosystem which may give harm to the balance of the ecosystem. With regard to the mentioned case, under the supervision of the Ministry, a project is in progress for the inspection of fish farms by a private company under the relevant National 
and International legislation, with which the locations and coordinates of the farms to be determined and the risk of maritime accidents minimized and protection of life, property and marine environment provided.

There are also other accidents take place in the fish farms, such as rope breakage or failures in the crane hydraulic systems during feeding or harvesting of fish. Determining the location of the farms is an important matter in terms of rescuing the crew at work and quick intervention when necessary. In Nordic countries such as Norway, England and
Scotland where salmon and other aquaculture farms are located at sea, there are records of accidents in farms that were caused by crane failure, rope breakage, falling, drowning etc. In these countries, governmental bodies such as Coast Guard, General Directorate of Coastal Safety, Marine Accidents Investigation Bureau carry out joint efforts with aquaculture sector in order to raise awareness with regard to maritime safety, share their experience and determine the challenges and measures in the working environment. (Anonymus, 2017d).

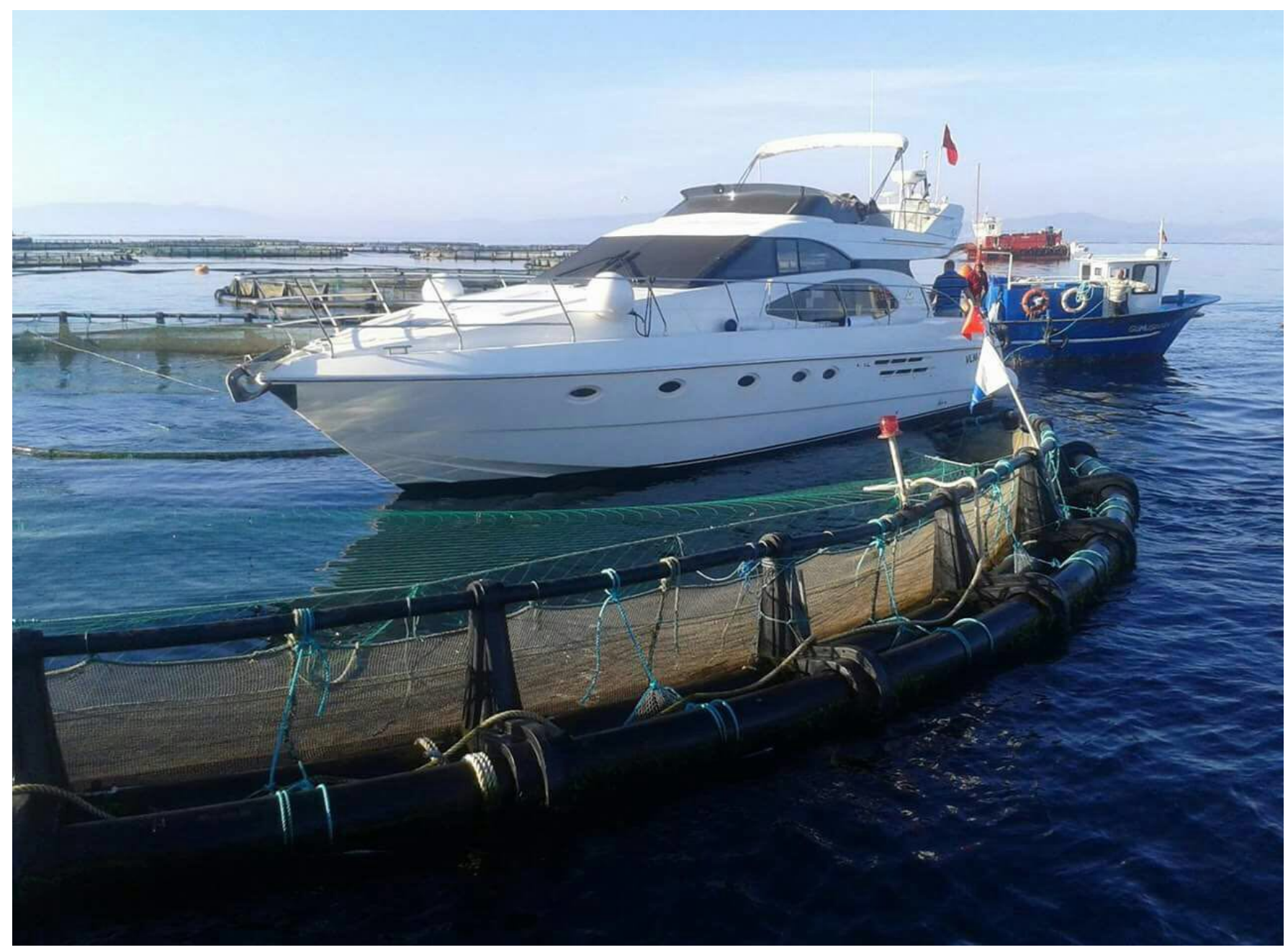

Picture 3. Marine accident example in fish farming 


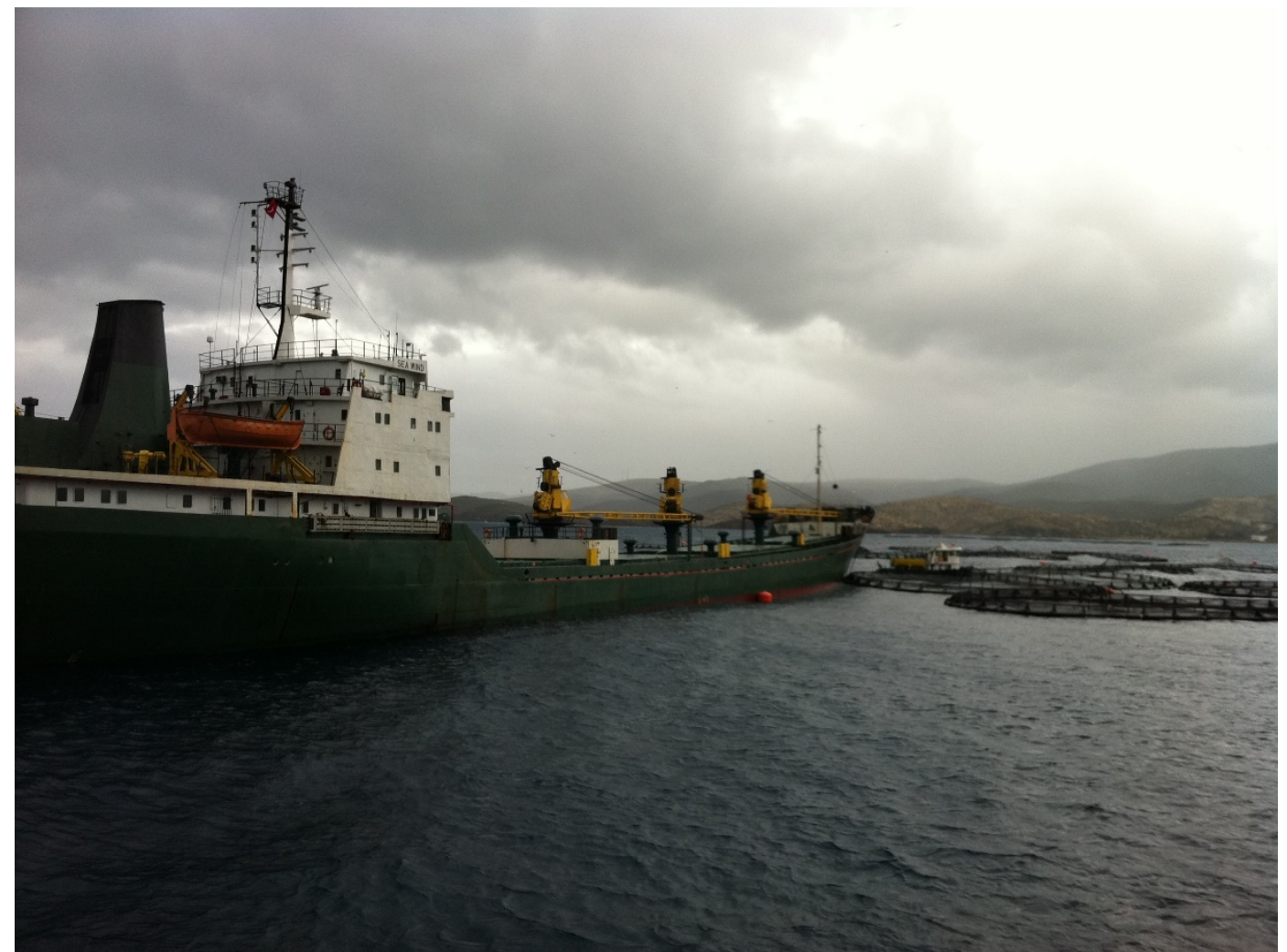

Picture 4. Marine accident example in fish farming

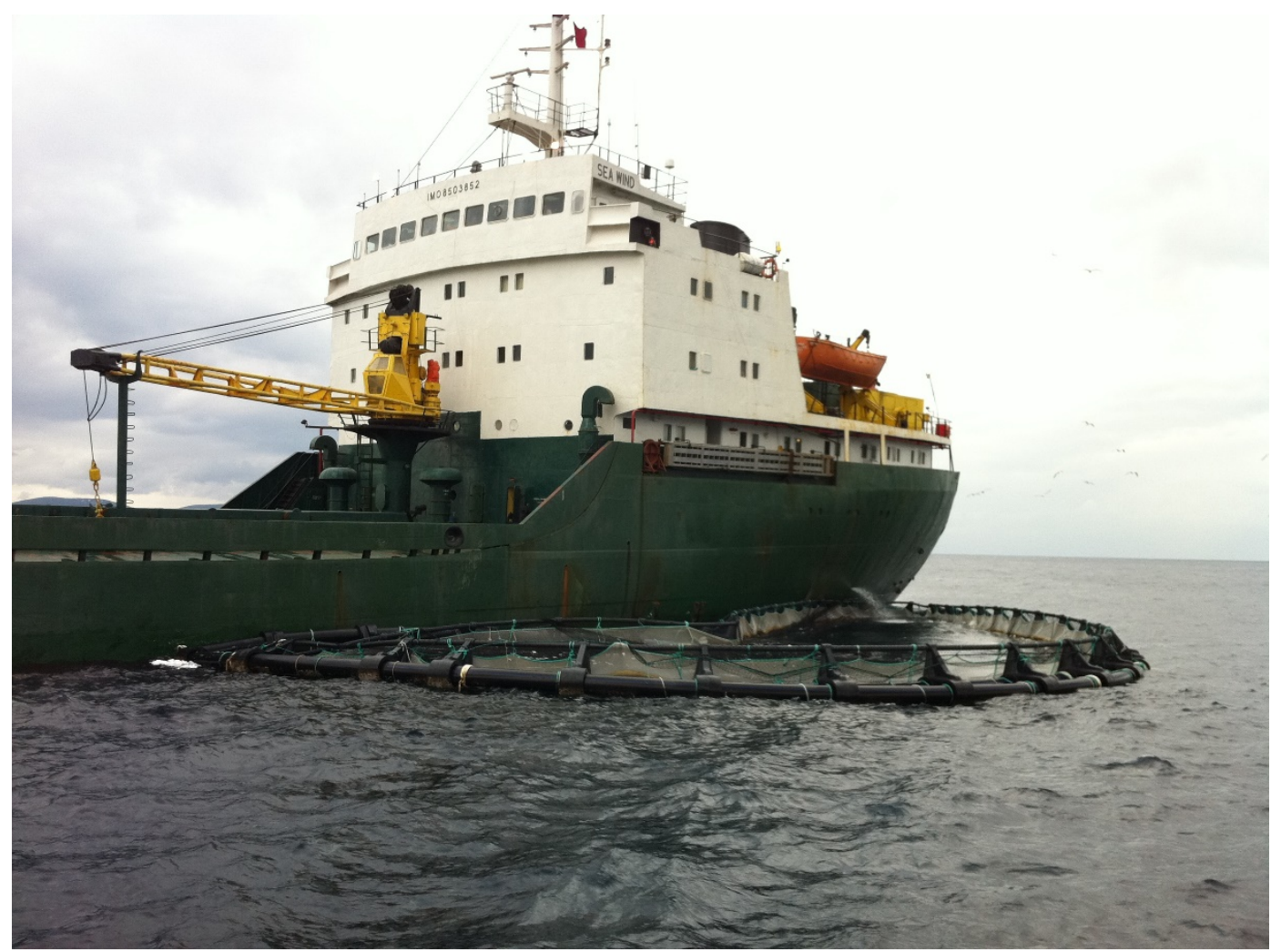

Picture 5. Marine accident example in fish farming 


\section{Conclusions}

It is very important, for Turkey too, to carry out studies in this regard. The aquaculture sector is an emerging sector for the Turkish economy which is open for development. But marine environment has its challenges and risks against which due measures and precautions waiting to be taken. In order to protect the ecosystem of the seas and ensure a healthy and safe fish farming, it is a priority for the stakeholders in the aquaculture sector to cooperate and organize meetings. In the aquaculture industry, practical and applicable solutions are needed to contribute to the improvement of maritime safety, in particular for determining the causes of the accidents and safety related issues that may arise and how to address them.

\section{References}

Anonymus (2017a). Ministry of Food, Agriculture and Livestock Fishery Statistics (2017). https://www.tarim.gov.tr/sgb/Belgeler/SagMenuVeriler/BSGM.pdf (accessed 25.11.17)

Anonymus (2017b). Lady Tuna. https://www.marinetraffic.com/tr/ais/details/ships/374762000 (accessed 17.11.17)

Anonymus (2017c). Çeşme kıyılarından M/V Lady Tuna'dan sizan petrol temizleniyor. http://www.kaptanhaber.com/cesme-kiyilarindan-mv-lady-tunadan-sizan-petrol-temizleniyor/45065/ (accessed 25.11.17)

Anonymus (2017d). Helping to Prevent Accidents at Scottish Fish Farms-Fishuptade.com https://www.fishupdate.com/helping-to-prevent-accidents-at-scottish-fish-farms-fishupdate-com/ (accessed 15.11.17)

Ece, J.N. (2016). Kılavuzluk Hizmetlerinin Deniz Emniyetine Katkısı: İstanbul Boğazı'nda Kazaya Karışan Gemiler İle Kilavuz Kaptan Almaları Arasındaki İlişkinin Analizi. Journal of ETA Maritime Science, 4(1), 3-21.

Erkan, N., Özden, Ö. (2007). Proximate Composition and Mineral Contents in Aqua Cultured Sea Bass (Dicentrarchus labrax), Sea Bream (Sparus aurata) Anaylzed by ICP-MS. Food Chemistry, 102, 721-725.
Erkan, N. (2013). Türkiye'de Tüketilen Su Ürünlerinin

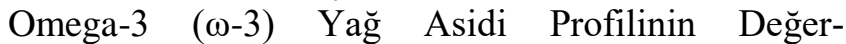
lendirilmesi. Journal of FisheriesSciences.com, 78(2), 194-208.

FAO (2016). The State of World Fisheries and Aquaculture 2016, 200 pp. Rome, ISBN 978-92-5-109185-2

Hsu, W-K.K. (2012). Ports' Service Attributes for Ship Navigation Safety. Safety Science, 50, 244-252.

İstikbal, C. (2007). Denizde Risk Nedir, Nasıl Değerlendirilir? http://www.denizgazete.com/yazarlar/cahitistikbal/denizde-risk-nedir-nasil-degerlendirilir/100163/ (accessed 10.11.17)

İstikbal, C. (2016). Turkish Straits: Difficulties and Role of Pilotage. http://www.seanews.com.tr/news/160485/TurkishStraits-Difficulties-and-Role-of-Pilotage.html (accessed 10.11.17)

Rabanal, H. (1988). History of Aquaculture. ASEAN/UNDP/FAO Regional Small-Scale Coastal Fisheries Development Project Manila, Philippines, http://www.fao.org/3/a-ag158e.pdf $\quad$ (accessed 10.11.17)

Wang, J. (2006). Maritime Risk Assessment and its Current Status. Quality and Reliability Engineering International, 22, 3-19.

Wu, B., Yan, X., Wang, Y., Guedes Soares, C. (2017). An Evidential Reasoning-Based CREAM to Human Reliability Analysis in Maritime Accident Process. Risk Analysis, 37(10), 1936-1957.

Zhang, J., Teixeira, A.P., Guedes Soares, C., Yan, X., Liu, K. (2016). Maritime Transportation Risk Assessment of Tianjin Port with Bayesian Belief Networks. Risk Analysis, 36(6), 1171-1187. 